\title{
Perilaku Hygiene Organ Reproduksi Pada Remaja Putri Di Sman Olahraga Rumbai Pekanbaru
}

\author{
Chairil, Dien Fadillah \\ Universitas M uhammadiyah Riau \\ Corespodence Email : chairil@umri.ac.id
}

\begin{abstract}
Background Behavioral hygiene of reproductive organs An effort of a person (young women) in improving health by maintaining the cleanliness of reproductive organs. Purpose: This study is to determine the hygiene behavior of reproductive organs in adolescent girls at Rumbai Pekanbaru High School sports. M ethod: The design of this study is the sampling technique probality sampling technique, amounting to 49 respondents, data collection using a questionnaire. Results: research conducted on January 28, 2019 obtained results about that respondents in the category of good behavior are all respondents, namely 49 respondents (100\%).So the hygiene behavior of female students at the Rumbai Pekanbaru high school sports is included in the category of good behavior, but there are still some students who do not use tissue after BAK, do not use cotton pants, do not change pads in one day, use narrow underwear and do not use soap, because all include hygiene behavior in maintaining the cleanliness of the reproductive organs.
\end{abstract}

Keywords: Reproductive Organ Hygiene, Behavior

\begin{abstract}
Abstrak
Latar Belakang Perilaku hidup bersih organ reproduksi U paya seseorang (wanita muda) dalam meningkatkan kesehatan dengan menjaga kebersihan organ reproduksi. Tujuan: Penelitian ini untuk mengetahui perilaku higienis organ reproduksi pada remaja putri di sekolah menengah olahraga Rumbai Pekanbaru. M etode: Desain penelitian ini adalah teknik pengambilan sampel teknik probality sampling, berjumlah 49 responden, pengumpulan data menggunakan kuesioner. Hasil: penelitian yang dilakukan pada tanggal 28 Januari 2019 diperoleh hasil tentang bahwa responden dalam kategori perilaku baik adalah semua responden, yaitu 49 responden (100\%). Jadi perilaku higienis siswa perempuan di sekolah menengah olahraga Rumbai Pekanbaru termasuk dalam kategori perilaku yang baik, tetapi masih ada beberapa siswa yang tidak menggunakan tisu setelah BAK, tidak menggunakan celana katun, tidak mengganti pembalut dalam satu hari, menggunakan pakaian dalam yang sempit dan tidak menggunakan sabun, karena semua termasuk perilaku hidup bersih dalam memelihara kebersihan organ reproduksi.
\end{abstract}

Kata Kunci : Kebersihan Organ Reproduksi, Perilaku

Received: 2 January 2020, Accepted : 31 M ay 2020 - M ay 2020 - Jurnal Photon V ol.10 No.2

DOI : https://doi.org/10.37859/jp.v10i2.1792

PHOTON is licensed under a Creative Commons Attribution-ShareAlike 4.0 International License 


\section{Introduction}

Kebersihan organ reproduksi sangatlah penting bagi setiap wanita karena organ reproduksi bersifat sensitif dan harus di jaga.Perilaku tersebut harus ditanamkam sejak dini oleh para remaja putri agar terjaganya kebersihan dan kanyamanan pada diri remaja itu sendiri apa lagi bnyaknya perubahan perubahan yg terjadi pada diri remaja.(Sobur, 2009). Pada masa remaja, individu mengalami berbagai perubahan baik fisik maupun psikis. Konsep diri juga dalam keadaan yang terus berubah. Semenjak konsep diri terbentuk, seseorang akan berperilaku sesuai dengan konsep dirinya tersebut. A pabila perilaku seseorang tidak konsisten dengan konsep dirinya, maka akan muncul perasaan tidak nyaman dalam dirinya. (Mayasari, 2008). Perubahan yang cepat memberikan konsekuensi bagi individu untuk dapat menyesuaikan diri dengan tuntutan lingkungan yang semakin lama semakin meningkat.Tuntutan untuk menyesuaikan diri dengan lingkungan mengakibatkan perubahan nilai-nilai sosial budaya yang berpengaruh pada konsep diri dan perilaku seseorang.(M ayasari, 2008).

Dalam upaya meningkatkan kualitas sumber daya manusia, remaja sebagai generasi penerus bangsa perlu diperhatikan.Pada masa remaja, individu mengalami berbagai perubahan baik fisik maupun psikis. Remaja mengalami perubahan secara kognitif dan mulai mampu berfikir seperti orang dewasa. Pada periode ini remaja melepaskan diri secara emosional dari orang tua dalam menjalankan peran sosialnya yang baru sebagai orang dewasa. M engenai beberapa perubahan tersebut, konsep diri juga dalam keadaan yang terus berubah (A rini, 2008). Perubahann fisik yang tampak jelas pada remaja yaitu tubuh berkembang pesat sehingga mencapai bentuk orang dewasa yang disertai pula dengan berkembangnya kapasitas reproduksi, sehingga remaja perlu memahami tentang pentingnya kesehatan reproduksi. Kesehatan reproduksi remaja adalah suatu kondisi sehat yang menyangkut sistem, fungsi dan proses reproduksi yang dimiliki oleh remaja (Wiknjosastro, 2008).

Pengetahuan remaja tentang kesehatan reproduksi masih kurang, $86 \%$ remaja kurang mengetahui tentang kesehatan reproduksi. Salah satu organ tubuh yang sensitif dan memerlukan perawatan khusus adalah alat reproduksi. Pengetahuan dan perawatan yang baik merupakan faktor penentu dalam memelihara kesehatan reproduksi (Siswono, 2001). Kurangnya kebersihan organ reproduksi merupakan salah satu penyebab infeksi alat reproduksi seperti Keputihan,Kanndidiasis Vulbovaginitis Vaginosis bacterial, dan Trikomoniasis. dan Infeksi alat reproduksi luar bisa masuk sampai ke alat reproduksi dalam dan menyebabkan kanker rahim (Pinem, 2012).

M enjaga kesehatan berawal dari menjaga kebersihan. $\mathrm{Hal}$ ini juga berlaku bagi kesehatan organ organ seksual, termasuk vagina.Kurangnya higienitas merupakan salah satu penyebab infeksi alat reproduksi yang dialami $20 \%$ hingga 25\% pada remaja.(Siswono, 2001). SM AN Olahraga merupakan salah satu SM A yang terdapat di kota Pekanbaru.Berdasarkan hasil data yang di peroleh di SM A Olahraga Pekanbaru jumlah remaja putri kelas X dan XI adalah 95 orang. Berdasarkan survey awal yang dilakukan peneliti di SM A Olahraga pada tanggal 31 A gustus 2019 menunjukkan bahwa dari 10 reponden yang dilakukan penelitian terdapat 10 orang (100\%) yang dalam satu hari mengganti pakaian dalam, 9 orang (90\%) yang membersihkan alat genetalia setelah BAK, 1 orang $(10 \%)$ yang tidak membersihkan al at genetalia setelah BAK, 4 orang $(40 \%)$ yang tercium bau atau terasa gatal (tidak nyaman) pada sekitar kemaluan, 6 orang $(60 \%)$ yang tidak tercium bau atau terasa gatal (tidak nyaman) pada sekitar kemaluan, 10 orang (100\%) yang mengganti pembalut dalam satu hari, dan 10 orang (100\%) yang membuang bekas pembalut ditempat yang aman.

Received: 2 January 2020, Accepted : 31 M ay 2020 - M ay 2020 - Jurnal Photon V ol.10 No.2 DOI : https://doi.org/10.37859/jp.v10i2.1792

PHOTON is licensed under a Creative Commons Attribution-ShareAlike 4.0 International License 


\section{The M ethods}

Pengumpulan data adalah proses pendekatan kepada subjek yang diperlukan dalam suatu penelitian. Proses pengumpulan data dilakukan ditempat penelitian dengan prosedur sebagai berikut :

Dalam penelitian ini instrumen yang digunakan adalah dengan kuesioner, Kuesioner dalam penelitian ini menggunakan kuisioner modifikasi berdasarkan penelitian sebelumnya yaitu kuisioner dari penelitian Pengumpulan data dilakukan untuk mengetahui hubungan antara konsep diri dengan perilaku hygiene organ reproduksi pada remaja putri di SM AN olahraga rumbai pekanbaru, adapun jenis pertanyaan yang digunakan adalah pertanyaan tertutup yang berbentuk Dichotomous Choice. Dalam pertanyaan ini hanya disediakan 2 jawaban/ alternatif dan responden hanya memilih satu diantaranya (N otoatmodjo, 2005). Dalam pengumpulan data penelitian mengunakan data primer, yaitu pengumpulan data dilakukan dengan cara penyebaran kuesioner.

\section{Result and Discussion}

Berdasarkan penelitian yang dilakukan pada tanggal 28 Januari 2019 di SM AN Olahraga Rumbai Pekanbaru dapat diperoleh data-data mengenai Perilaku Hygiene Organ Reproduksi pada Remaja Putri sebagai berikut:

Tabel 1. Distribusi Frekuensi Umur Responden di SM AN Olahraga Rumbai Pekanbaru Januari 2019

\begin{tabular}{lccc}
\hline No & Umur responden & $\begin{array}{c}\text { Frekuensi } \\
(\mathrm{f})\end{array}$ & $\begin{array}{c}\text { Persentase } \\
(\%)\end{array}$ \\
\hline 1 & 14 & 1 & 2.0 \\
2 & 15 & 13 & 26.5 \\
3 & 16 & 31 & 63.3 \\
4 & 17 & 4 & 8.2 \\
5 & Total & 49 & 100.0 \\
\hline
\end{tabular}

Tabel 2. Distribusi Frekuensi Kelompok Umur Responden di SM AN Olahraga Rumbai Pekanbaru Januari 2019

\begin{tabular}{llcc}
\hline No & Kelompok umur & $\begin{array}{c}\text { Frekuensi } \\
(\mathrm{f})\end{array}$ & $\begin{array}{c}\text { Persentase } \\
(\%)\end{array}$ \\
\hline 1 & AKHIR & 4 & 8.2 \\
2 & MADYA & 45 & 91.8 \\
& Total & 49 & 100.0 \\
\hline
\end{tabular}

Received: 2 January 2020, Accepted : 31 M ay 2020 - M ay 2020 - Jurnal Photon V ol.10 No.2

DOI : https://doi.org/10.37859/jp.v10i2.1792

PHOTON is licensed under a Creative Commons Attribution-ShareAlike 4.0 International License 
Tabel 3. Distribusi Frekuensi Kelas Responden di SM AN Olahraga Rumbai Pekanbaru Januari 2019

\begin{tabular}{llcc}
\hline No & Kelas & $\begin{array}{c}\text { Frekuensi } \\
(\mathrm{f})\end{array}$ & $\begin{array}{c}\text { Persentase } \\
(\%)\end{array}$ \\
\hline 1 & XIPS 1 & 4 & 8.2 \\
2 & XIPS2 & 3 & 6.1 \\
3 & XIPS3 & 3 & 6.1 \\
4 & XIPS4 & 5 & 10.2 \\
5 & XIIPS2 & 7 & 14.3 \\
6 & XIIPS 3 & 7 & 14.3 \\
7 & XIIPS4 & 6 & 12.2 \\
8 & XI MIA 1 & 6 & 12.2 \\
9 & XI MIA 2 & 8 & 16.3 \\
10 & Total & 49 & 100 \\
\hline
\end{tabular}

Tabel 4. Distribusi Frekuensi Personal Hygiene Responden di SM AN Olahraga Rumbai Pekanbaru Januari 2019

\begin{tabular}{llccc}
\hline No & & Personal hygiene & $\begin{array}{c}\text { Frekuensi } \\
(\mathrm{f})\end{array}$ & $\begin{array}{c}\text { Persentase } \\
(\%)\end{array}$ \\
\hline 1 & Ya & 49 & 100 \\
2 & Tidak & 0 & 0 \\
\hline
\end{tabular}

Tabel 5. Distribusi Frekuensi M enggunakan Tisu Setelah BAK Responden di SM AN Olahraga Rumbai Pekanbaru Januari 2019

\begin{tabular}{llcc}
\hline No & M enggunakan tisu setelah BAK & $\begin{array}{c}\text { Frekuensi } \\
(\mathrm{f})\end{array}$ & $\begin{array}{c}\text { Persentase } \\
(\%)\end{array}$ \\
\hline 1 & Ya & 29 & 59.2 \\
2 & Tidak & 20 & 40.8 \\
& Total & 49 & 100.0 \\
\hline
\end{tabular}

Received: 2 January 2020, Accepted : 31 M ay 2020 - M ay 2020 - Jurnal Photon V ol.10 No.2 DOI : https://doi.org/10.37859/jp.v10i2.1792

PHOTON is licensed under a Creative Commons Attribution-ShareAlike 4.0 International License 
Tabel 6. Distribusi Frekuensi M enggunakan Celana Dalam Berbahan Katun Responden di SM AN Olahraga Rumbai Pekanbaru

Januari 2019

\begin{tabular}{|c|c|c|c|}
\hline No & $\begin{array}{c}\text { M enggunakan celana dalam berbahan } \\
\text { katun }\end{array}$ & $\begin{array}{l}\text { Frekuensi } \\
\text { (f) }\end{array}$ & $\begin{array}{l}\text { Persentase } \\
(\%)\end{array}$ \\
\hline 1 & $\mathrm{Ya}$ & 44 & 89.8 \\
\hline 2 & Tidak & 5 & 10.2 \\
\hline & Total & 49 & 100.0 \\
\hline
\end{tabular}

Tabel 7. Distribusi Frekuensi M engganti Celana Dalam Setelah Berolahraga Responden di SM AN Olahraga Rumbai Pekanbaru Januari 2019

\begin{tabular}{|c|c|c|c|}
\hline No & M engganti celana setelah berolahraga & $\begin{array}{l}\text { Frekuensi } \\
\text { (f) }\end{array}$ & $\begin{array}{c}\text { Persentase } \\
(\%)\end{array}$ \\
\hline 1 & $\mathrm{Ya}$ & 49 & 100 \\
\hline 2 & Tidak & 0 & 0 \\
\hline & Total & 49 & 100 \\
\hline
\end{tabular}

Tabel 8. Distribusi Frekuensi M engganti Pembalut Dalam Satu Hari Responden di SM AN Olahraga Rumbai Pekanbaru Januari 2019

\begin{tabular}{|c|c|c|c|}
\hline No & M engganti pembalut dalam satu hari & $\begin{array}{c}\text { Frekuensi } \\
\text { ( F ) }\end{array}$ & $\begin{array}{c}\text { Persentase } \\
(\%)\end{array}$ \\
\hline 1 & Ya & 48 & 98.0 \\
\hline 2 & Tidak & 1 & 2.0 \\
\hline & Total & 49 & 100 \\
\hline
\end{tabular}

Tabel 9. Distribusi Frekuensi M enjaga Kebersihan Organ Reproduksi Responden di SM AN Olahraga Rumbai Pekanbaru Januari 2019

\begin{tabular}{|c|c|c|c|}
\hline No & M enjaga kebersihan organ reproduksi & $\begin{array}{l}\text { Frekuensi } \\
\text { (f) }\end{array}$ & $\begin{array}{c}\text { Persentase } \\
(\%)\end{array}$ \\
\hline 1 & Ya & 49 & 100 \\
\hline \multirow[t]{2}{*}{2} & Tidak & 0 & 0 \\
\hline & Total & 49 & 100 \\
\hline
\end{tabular}

Received: 2 January 2020, Accepted : 31 M ay 2020 - M ay 2020 - Jurnal Photon V ol.10 N 0.2 DOI : https://doi.org/10.37859/jp.v10i2.1792

PHOTON is licensed under a Creative Commons Attribution-ShareAlike 4.0 International License 
Tabel 10. Distribusi Frekuensi M engganti Celana Dalam Dalam Satu Hari Responden di SM AN Olahraga Rumbai Pekanbaru Januari 2019

\begin{tabular}{|c|c|c|c|}
\hline No & $\begin{array}{c}\text { M engganti celana dalam dalam satu } \\
\text { hari }\end{array}$ & $\begin{array}{l}\text { Frekuensi } \\
\text { (f) }\end{array}$ & $\begin{array}{c}\text { Persentase } \\
(\%)\end{array}$ \\
\hline 1 & $\mathrm{Ya}$ & 49 & 100 \\
\hline 2 & Tidak & 0 & 0 \\
\hline & Total & 49 & 100 \\
\hline
\end{tabular}

Berdasarkan penelitian yang dilakukan pada tanggal 28 Januari 2019 di SMAN Olahraga Rumbai Pekanbaru dengan judul “Perilaku Hygiene Organ Reproduksi pada Remaja Putri di SM AN Olahraga Rumbai Pekanbaru" Menurut hasil yang diperoleh dari penelitian ini dinyatakan bahwa responden yang kategori prilaku baik adalah keseluruhan responden yaitu 49 responden (100\%), responden pada kategori umur remaja akhir sebanyak 4 responden (8,2\%), sedangkan responden pada kategori umur madya sebanyak 45 responden $(91,8 \%)$.

Karakteristik individu meliputi berbagai variable seperti motif, nilai-nilai, sifat kepribadian, dan sikap yang saling berinteraksi satu sama lain kemudian berinteraksi pula dengan faktor-faktor lingkungan dalam menentukan perilaku. Faktor lingkungan memiliki kekuatan besar dalam menentukan perilaku, bahkan kadang-kadang kekuatannya lebih besar daripada karakteristik individu (Azwar, 2011).Penerimaan perilaku baru atau adopsi perilaku melalui proses seperti ini dimana didasari oleh pengetahuan, kesadaran dan sikap yang positif (long lasting). Sebaiknya apabila perilaku itu tidak didasari oleh pengetahuan dan kesadaran, maka tidak akan berlangsung lama. Perilaku tidak mendukung juga di karenakan faktor interna dan eksterna, dimana lingkungan sekitar dan lingkungan keluarga berperan penting.

Selanjutnya dari data pada penelitian ini yang telah dilakukan pada siswi SM AN Olahraga Rumbai Pekanbaru diperoleh data yang menggunakan tisu setelah BAK sebanyak 29 responden $(59,2 \%)$ dan yang tidak menggunakan tisu setelah BAK sebanyak 20 responden (40,8\%). Yang menggunakan celana dalam berbahan katun sebanyak 44 responden $(89,8 \%)$ dan yang tidak menggunakan celana dalam berbahan katun sebanyak 5 responden $(10,2 \%)$. Yang mengganti pembalut dalam satu hari sebanyak 48 responden $(98,0 \%)$, dan yang tidak mengganti pembalut dalam satu hari sebanyak 1 responden $(2,0 \%)$. Yang tidak menggunakan pakaian dalam yang sempit sebanyak 43 responden (87,8\%), sedangkan yang menggunakan pakaian dalam yang sempit sebanyak 6 responden $(12,2 \%)$. Yang menggunakan sabun sebanyak 41 responden (83.7\%), sedangkan yang tidak menggunakan sabun sebanyak 8 responden (16.3\%). Dan yang banyak minum air putih sebanyak 46 responden $(93,3 \%)$, sedangkan yang tidak banyak minum air putih sebanyak 3 responden $(6,1 \%)$.

Hasil penelitian yang dilakukan oleh Rofika Rahman (2013) Berdasarkan hasil penelitian diperoleh bahwa responden yang memiliki sikap baik sebanyak 37 orang (57.8\%) dan yang memiliki sikap kurang sebanyak 27 orang (42.2\%). Sikap adalah reaksi atau respon yang masih tertutup terhadap stimulus atau objek (Notoatmodjo, 2007). Sikap yang ada dalam diri seseorang memerlukan unsur respon dan stimulus. Kepuasan merupakan respon dari stimulus yang diterima. O utput sikap pada seseorang dapat berbeda, jika

Received: 2 January 2020, Accepted : 31 M ay 2020 - M ay 2020 - Jurnal Photon V ol.10 No.2 DOI : https://doi.org/10.37859/jp.v10i2.1792

PHOTON is licensed under a Creative Commons Attribution-ShareAlike 4.0 International License 
suka maka seseorang akan mendekat, mencari tahu, dan bergabung, sebaliknya jika tidak suka, maka seseorang akan menghindar dan menjauh (Budiman, 2013).

Hasil penelitian menunjukan dari total 85 responden sebagian besar remaja memiliki perilaku positif sebanyak 50 (58.8\%) remaja sedangkan memiliki perilaku negatif sebanyak $35(41.2 \%)$ remaja. Keberadaan sarana prasarana berupa fasilitas kesehatan dan fasilitas lain yang mendukung perilaku vulva hygiene juga menjadi salah satu faktor yang berpengaruh terhadap perilaku vulva hygiene. Keberadaan berbagai sarana dan prasarana menyebabkan responden mudah untuk mendapatkan hal-hal yang mendukung perilaku vulva hygiene, seperti tisu basah, handuk yang lembut, celana dalam yang lembut dan nyaman, pembalut wanita, air bersih untuk membersihkan vagina dan lain sebagainya. Kemudahan dalam mendapatkan barang-barang tersebut akan memudahkan responden dalam melakukan perilaku vulva hygiene, sehingga mendorong responden untuk berperilaku vulva hygiene yang baik.

\section{KESIM PULAN}

Perilaku hygiene organ reproduksi Suatu usaha seseorang (remaja putri) dalam memperbaiki kesehatan dengan memelihara kebersihan organ reproduksi.

Berdasarkan hasil yang dilakukan di SM AN O lahraga Rumbai Pekanbaru dengan cara menyebarkan lembar kuisioner yang berisikan 10 pernyataan sesuai dengan masalah yang diteliti, bahwa remaja yang diteliti merupakan kelas X dan XI dengan hasil analisis didapatkan rata rata umur termuda 14 tahun dan umur tertua 17 tahun. Dinyatakan bahwa responden yang kategori prilaku baik adalah keseluruhan responden yaitu 49 responden (100\%),

\section{References}

A rini A. 2006. Konsep Diri Positif, Menentukan Presentasi Anak. Yogyakarta: Kanisius.

Azwar, S. 2007.Sikap Manusia, Teori dan Pengukurannya.Jakarta: Pustaka Pelajar

H andayani. 2011. Kesehatan Reproduksi. Jakarta: EGC

Kepmenkes, RI. 2015. Situasi Kesehatan Reproduksi Remaja. Jakarta: Pusat Data dan Informasi Kementrian Kesehatan RI.

Lestari, Tri. 2013. Buku Ajar Kesehatan Reproduksi. Jakarta: EGC

Linda, J.2005. Kesehatan Reproduksi Remaja dan Wanita. Jakarta: Salemba Medika

M iraningsih, W ahyu. 2013. Hubungan Antara Interaksi Sosial Dan Konsep Diri Dengan Perilaku Reproduksi

Sehat Pada Siswa Kelas XI Di MAN Purworejo [Skripsi]. Semarang: U niversitas N egeri Semarang.

N otoatmodjo. 2005. Promosi Kesehatan Teori Dan A plikasi. Jakarta :Rineka Cipta.

N ursalam. 2010. Konsep Dan Penerapan M etode Penelitian I/mu Keperawatan.Jakarta: Salemba M edica.

Pinem, Sahora. 2012. Kesehatan Reproduksi dan K eluarga Berencana. Jakarta: Trans Info M edia.

Sobur. 2009. Psikologi Umum Dalam Lintas Sejarah. Bandung: Pustaka Setia.

Tuhumena, H. 2006. Upaya Membentuk Konsep Diri yang Positif dalam Rangka Menurunkan kecenderungan Berperilaku Agresif pada Remaja, Jurnal Psikologi Vol.1, Nomor 1, Maret 2006.

Bandung : Fakultas Psikologi U niversitas Padjadjaran

W iknjosastro H. 2008. I/mu Kebidanan. Jakarta : Bina Pustaka Sarwono Prawirohardjo Risnita. (2012).

Pengembangan Skala M odel Likert.

Received: 2 January 2020, A ccepted : 31 M ay 2020 - M ay 2020 - Jurnal Photon V ol.10 No.2

DOI : https://doi.org/10.37859/jp.v10i2.1792

PHOTON is licensed under a Creative Commons Attribution-ShareAlike 4.0 International License 